\title{
Competitive and Economically Feasible Cell Wall Disruption Techniques for Algal Biofuel Extraction
}

\author{
Umar Faruk J Meeranayak ${ }^{1}$, Shivasharana C. T. ${ }^{2}$ \\ ${ }^{1,2}$ Dept. of Biotechnology and Microbiology, Pavate Nagar, Karnatak University, Dharwad, Karnataka, India \\ *Corresponding Author: shivakud@gmail.com, Tel.: +919482081120
}

Available online at: www.isroset.org

Received: 19/Nov/2018, Accepted: 21/Dec/2018, Online: 31/Dec/2018

\begin{abstract}
In the present scenario of fuel and energy crises, attempts for bridging the gap between demand and supply remained ineffective. The environmental damage caused by the existing fossil fuel facing price hike day by day, simultaneously the fossil fuel reservoirs are also exhausting and hence, these alarming energy crises are need to be addressed immediately. Today, the scientific community is running behind the renewable alternative fuel sources, and biofuel is one such alternative. The limitations of first and second generation biofuel have created the way for third generation biofuel technology. Microalgae are the major sources of the third generation biofuel. In order to achieve the high lipid content, we need to modify the pretreatment methods for disrupting the cell wall of microalgae. The classical method of lipid extractions from plants and crops can be followed for third generation biofuel production with trivial modifications in operating conditions. Several cell disruption techniques are known since past, but economically feasible, energy efficient and easily manageable methods are yet to identify, optimize and appraise. In the current review article, we have made an attempt to convey the algal cell wall components which are broadly used in the research and industrial area and focused on the key techniques involved in algal cell disruption.
\end{abstract}

Keywords-Microalgae, Biofuel, Cell wall, Lipid, Biomass

\section{INTRODUCTION}

Introduction Unsuccessful attempts in fulfilling the purpose of fuel and energy crises still unrelenting in the $20^{\text {th }}$ century. Along with the environmental pollution, continuous ramble in price and demand of these fossil fuel reservoirs are challenging for the future that is needed to be addressed immediately. There are several obstacles and economic challenges need to be tackled in order to meet the fuel crises. Worldwide, as these non-renewable energy resources are running short of supply, the mankind is looking for an alternative source like the natural and renewable energy sources e.g. Biofuel. Earlier, the $1^{\text {st }}$ and $2^{\text {nd }}$ generation biofuels were excavated with the aid of versatile crops and their residues but, unconditionally growing population and the demand for the food supply created a problem in using these first and second generation biofuel sources hence, they failed in filling the gap [1]. Because, in order to cope up with the growing population needs such as energy and food supply, there is a need for considerable agriculture land. As first generation biofuel depended on the sources which are valuable edible sources as well [2]. In case of secondgeneration biofuel, the non-edible sources were utilized. However, the expenses in obtaining the lingo-cellulosic material in a desired level from raw materials and the processing technology were not fit for further commercial up gradation. The limitations of first and second generation biofuel led the way for emerging of third generation biofuel technology. This led the researchers to find and formulate $3^{\text {rd }}$ generation biofuel from algae and the algal oil. Despite of the facts, that the algae cannot competitive with fossil fuel, they still have many advantages over plants [3].

There are mainly 4 major steps involved in obtaining biofuel from algae viz. cultivating algal biomass, biomass harvesting, lipid extraction and translation of lipids into biodiesel. However, each step has its own challenges. Basically, in order to take out lipids from the microalgae, it needs a massive amount of microalgal biomass and worldwide the techniques for growing algae for biomass production are in research phase. There are ample of parameters need to be taken care of, starting from obtaining microalgal biomass till it is processed. Preliminarily fix between wet biomass and dry biomass is a Challenge. Because in the case of dry biomass, it is characterized that enormous amount of energy is required for drying, whereas wet biomass requires a very less energy input for lipid extraction. Although wet biomass considered as a better source for lipid extraction, the percentage of oil is less compared to that of dry biomass [4]. To exclude the Use of fossil fuel in future, we should search for an alternative feasible and sustainable method. Efforts in growing algal biomass, oil extraction, biofuel production are the interest of researchers. 
The classical method of lipid extractions from plants and crops can be followed for third generation biofuel production with trivial modifications in operating conditions. A little number of microalgae are explored for the biofuel production purpose [5] and these microalgae grows on wastewater sources and under extreme conditions as well possesses highest proportion of oil content with respect to its biomass which makes it a complementary source for biofuel production [6]. Microalgal biofuel usually is in the form of neutral lipid [7] and it is still not proven to be a potential source for commercial application because of the lack in effective technology for the extraction of oil from the algal biomass [8]. In order to obtain the high per cent of biofuel or lipids from the microalgae, it is equally necessary to culture the microalgal strains in optimized environmental conditions with suitable technology. Once we ensure the high percentage of lipid from the microalgae by looking at the amount of biomass available. Extraction can be followed by cell disruption techniques. Several cell disruption techniques are known since past, but the economically feasible methods are needed to be standardized.

In this review, an effort has been made in listing and discussing the several microalgal cell wall compositions, which are the well-known resources for biofuel production. As biofuel is the future of energy resource, microalgae plays a vital role in generating cheap and efficient biofuel. It is also important to exploit these microalgal resources in economically cost effective with high yield, for which the possible and efficient mechanical and non mechanical techniques, in the production of biofuel is explained briefly.

\section{MICROALGAE AND ITS CELL COMPONENTS}

Oil present inside the cell needs to be expelled out from the internal cell structures. For which several cell disruption methods are available (Figure.1). All the methods cannot be performed for all types of algal strains. Cell wall of microalgae usually made up of lipid constituents, protein components, polysaccharides glycoproteins and calcium carbonate $[9,10]$. However, the cell wall characteristics depended on the various factors of environment in which algae is growing [11]. Hence, the composition of cell wall differs from one species to another (Table.1). Prior to the selection of a method for extraction of lipids, it is always better to understand the components and composition of algae, respectively appropriate technology can be applied for lipid extraction by cell disruption. Presently there are several methods for cell disruption in use generally categorized as mechanical methods and non-mechanical methods. Some of the mechanical methods reported are Shear force, current, Heat and wave energy (Figure.2). The purpose of utilizing mechanical energy is to get the high yield. The oil extracted by the mechanical energy is more; however, more energy is spent. It is reported that the mechanical method of cell disruption induce more harshness to the cell environment inurn it may be an obstacle for the researchers while expecting other products [12]. In this review, we focused on the key developments and drawbacks faced by the researchers while extracting of lipid from the algae using cell wall disruption techniques and gives collective information about cell wall contents of various microalgae exploited for the biofuel production.

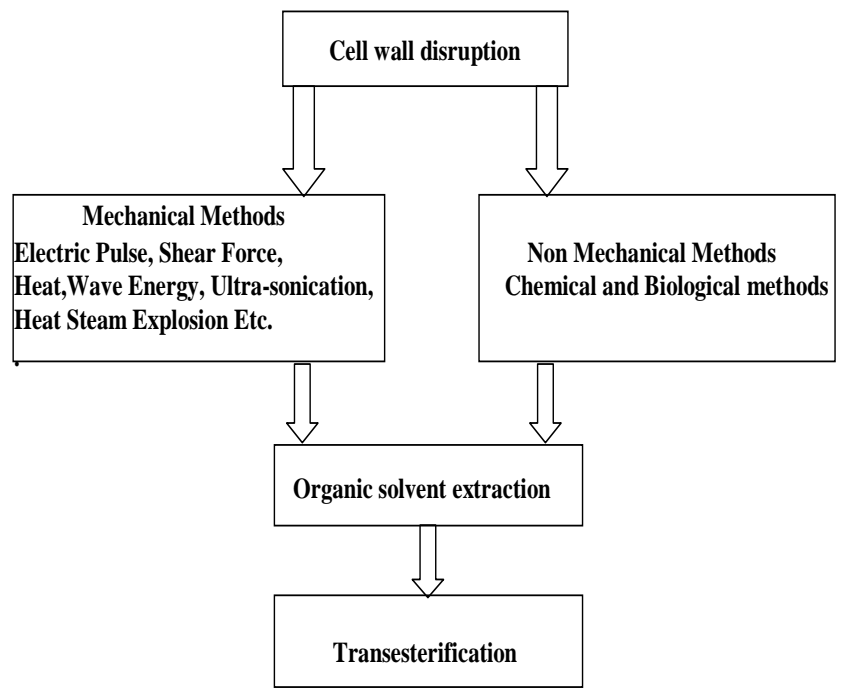

Figure 1. Steps Involved In the Oil Extraction from Microalgae.

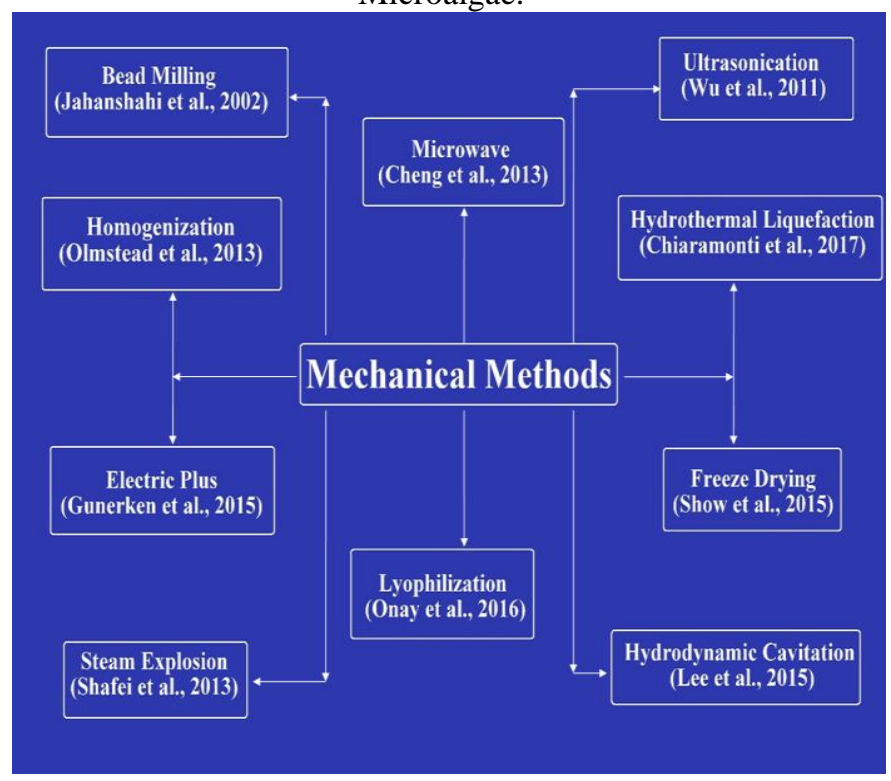

Figure 2. Represents the several Mechanical methods for cell disruption.

\{ Onay et al., 2016 [2], Jahanshahi et al., 2002 [13],Wu et al., 2011 [14],Cheng et al., 2013 [15], Olmstead et al., 2013 [16], Chiaramonti et al., 2017 [17], Show et al., 2015 [18], Gunerken et al., 2015 [19], Lee et al., 2015 [20], Shafei et al., 2013 [21] \} 
Table 1. Algal cell wall components.

\begin{tabular}{|c|c|c|}
\hline Algae & Cell wall components & References \\
\hline Acetabularia acetabulum & Mannans & {$[22]$} \\
\hline Anabaena cylindrical & Cellulose fibrils & {$[23]$} \\
\hline Anacystis nidulans & Mannose & {$[24]$} \\
\hline Botryococcus braunii & Variable Algeanan & {$[25]$} \\
\hline Caulerpa ambiguous & Glucose, xylose & {$[12]$} \\
\hline Chlamydomonas reinhardtii & Hyp-rich glycoproteins & {$[27]$} \\
\hline Chlamydomonas sp. & Arabinose + Hyp-rich Glycoproteins. & {$[28]$} \\
\hline Chlorella ellipsoidea & Cls,H-cls,pectin(no algaenan) & {$[29]$} \\
\hline Chlorella emersonii & TLS & {$[30]$} \\
\hline Chlorella fusca & Mannose, glucose, glucuronic acid, Rhaminose & {$[31]$} \\
\hline Chlorella pyrenoidosa & Pectin and cellulose & {$[32]$} \\
\hline Chlorella pyrenoidosa & Rhamnose/galactose & {$[28]$} \\
\hline Chlorella pyrenoidosa & Protein: Lipid: $\alpha$-Cls: H-cls: Gluamine: Ash(27\%: 9.2\%: 15.4\%:31\%: & {$[34]$} \\
\hline Chlorella saccharophila & 3.3\% : 5.2\%) & {$[35]$} \\
\hline Chlorella sp. & Cls,H-cls,pectin (no algaenan) & {$[26]$} \\
\hline Chlorella sp. & Microfibrils of chitin & {$[36]$} \\
\hline Codium fragile & TLS + Wall matrix +Rigid walls & {$[37]$} \\
\hline Codium fragile & Cellulose & {$[38]$} \\
\hline Dunaliella bioculata & Mannans & {$[34]$} \\
\hline Haematococcus Pluvialis & No cell wall & {$[24]$} \\
\hline Nannochloropsis oculata & Glucoseamine Blumreisinger & {$[32]$} \\
\hline Phormidium foveolarum & cellulosic polysaccharides & \\
\hline Tolypothrix tenuis & Mannose,Glucose & \\
\hline Chlorella ellipsoidea & Mannose,Glucose,Xylose & \\
\hline
\end{tabular}

\section{MECHANICAL METHODS}

Among the mechanical means of cell disruption bead milling technique is efficiently achieve the purpose and can be easily handled [13]. Other techniques such as electroporation, pulse field electroporation hydrodynamic cavitations are relatively time-consuming and labor intensive techniques. Earlier researchers have achieved highest lipid extraction in Nannochloropsissalina by using Hydrodynamic cavitations technique, comparing to the other mechanical methods such as autoclaving and ultra-sonication [20]. However, it has its own limitations. The freeze drying technique is reported as a less significant technique in lipid extraction [4]. Algae with its recalcitrant cell wall material can be broken down easily using the High-pressure homogenization technique [16]. Osmotic shock is not extensively reported. In an experiment, microwave applied for cell wall disruption, pectin and cellulose layers are cut opened and the porosity increased in the stipulated time period [15]. Microwave technique is effective in terms of time and energy. It is also noticed that increase in temperature enhanced the disruption efficiency [15]. Microwaves generate kind of vibrations inside the cell environment and because of the vibrational effects the molecular interactions inside the water molecules there is an increase of temperature occurs. This, in turn assists cell rupture.

Despite all these facts, it consumes high energy [39]. While working with Nannochloropsis sp., Teo and Idris observed the increased irradiation of microwave Technique [40]. Improvement in cell rupture capabilities is observed by the addition of various organic solvents and observed comparatively high lipid yield. This kind of cell disruption techniques are considered as physicochemical methods. Percentage of cell rupture and lipid productivity as observed by Teo and Idris by the microwave technique [40] method is summarized in Table 2. The ultrasound is used to rupture the cell wall in $C$. protothecoides[41] obtain significant yield. It is also reported that applying the high-speed ultrasound method can help in enhancing the cavitations in the subjected 
media. Which in turn result, improved cell wall disruption [42]. Similarly in an experiment conducted by the Pereira, used the ultrasound method along with the presence of Hexane [43], obtained a good yield. In the same way, Araujo, made a sincere attempt using the sonication technique along with the addition of silica by assuming that it may enhance cell disruption by increasing the sheer force [44]. However, unfortunately, the adverse effect of silica was noticed and the efficiency of yield is lowered. Thus, physicochemical method sometimes poses these kinds of challenges to the researchers. These problems need to be tackled.

\section{NON-MECHANICAL METHODS}

Due to the disadvantages like harshness, and high energy requirement and low efficiency of mechanical methods alternative and competent methods need to be developed. The chemical method of cell wall disruption is found effective and competent in nature. Basically, oils are soluble in organic solvents and hence, various solvent can be employed for the extraction of oil from microalgae. Solvents such as Hexane, Benzene, Methanol, and Chloroform can be used for the cell wall disruption. Chemical method is effective in terms of economic as well as energy efficiency. But some chemicals with their carcinogenic properties are a drawback. Otherwise, the solvents used for the cell wall disruption are proven good. Integrated approaches, like the combination of mechanical and non-mechanical method works better in most of the cases. In some reports, enzymes are stated to be used for cell disruption. However, enzymes are very specific in their action hence; there is a need for a selection of enzymes for the targeted algal cells.

Hence, it is a kind of chaotic method for working with enzymes; they are relatively costlier under lab scale works and its tedious job [18]. Apart from these mechanical and non mechanical methodologies, trends in extracting elevated amount of lipid and other intracellular composites from microalgae for the production of biofuel is grasping attention.

Table 2. Lipid yield by Microwave technique.

\begin{tabular}{|c|c|c|}
\hline Sl. No. & Solvent & Lipid yield (\%) \\
\hline 1. & Chloroform & 8.47 \\
\hline 2. & Dichloroform & 8.47 \\
\hline 3. & Hexane & 5.86 \\
\hline 4. & $\begin{array}{c}\text { Chloroform : }(1.5 \%) \text { Sodium } \\
\text { sulfate }\end{array}$ & 4.16 \\
\hline
\end{tabular}

\section{Conclusion}

To conclude, techniques discussed in this review article for the extraction of lipid content by disrupting the microalgal cell wall are potential. Different techniques sometimes can be employed by understanding the cell wall composition of microalgal species and sometimes depending on the compound which is targeted. Integrated approaches are economically most effective and energy consumption can be reduced with mechanical approaches by simply employing the useful solvents. The energy required for the mechanical method of cell wall breaking is a major drawback along with which most of the energy is dissipated in the form of heat. In several methods, the algae are allowed to expose for a longer duration, which poses complication with respect to the product quality. Most of the reports says the efficiency of mechanical cell disruption may be feasible at the laboratory scale however, while scaling up of the processes in large scale many times become expensive. Hence, these aspects need to be considered while designing the novel methods for cell wall rupturing, so that the algal products especially the algal biofuel may soon become a sustainable resource for the future fuel crises.

\section{REFERENCES}

[1] G. W. Huber, S. Iborra, and A. Corma, "Synthesis of Transportation Fuels from Biomass: Chemistry, Catalysts, and Engineering," ChemInform, vol. 37, no. 52, 2006.

[2] M. Onay, C. Sonmez, H. A. Oktem, and M. Yucel, "Evaluation of Various Extraction Techniques for Efficient Lipid Recovery from Thermo-Resistant Microalgae, Hindakia, Scenedesmus and Micractinium Species Comparison of Lipid Extraction Methods from Microalgae," American Journal of Analytical Chemistry, vol. 07, no. 02, pp. 141-150, 2016.

[3] V. Amanor-Boadu, P. H. Pfromm, and R. Nelson, "Economic feasibility of algal biodiesel under alternative public policies," Renewable Energy, vol. 67, pp. 136-142, 2014.

[4] A. Guldhe, B. Singh, I. Rawat, K. Ramluckan, and F. Bux, "Efficacy of drying and cell disruption techniques on lipid recovery from microalgae for biodiesel production," Fuel, vol. 128, pp. 46-52, 2014.

[5] Dragone G, Fernandes BD, Vicente AA, Teixeira JA. "Third generation biofuels from microalgae," Current research, technology and education topics in applied microbiology and microbial biotechnology, vol.2:1355-66, 2010.

[6] F. Alam, A. Date, R. Rasjidin, S. Mobin, H. Moria, and A. Baqui, "Biofuel from Algae," Advances in Biofuel Production, pp. 107119, 2013.

[7] M. J. J. Callejón, A. R. Medina, M. D. M. Sánchez, E. H. Peña, L. E. Cerdán, P. A. G. Moreno, and E. M. Grima, "Extraction of saponifiable lipids from wet microalgal biomass for biodiesel production," Bioresource Technology, vol. 169, pp. 198-205, 2014.

[8] P. Mercer and R. E. Armenta, "Developments in oil extraction from microalgae," European Journal of Lipid Science and Technology, vol. 113, no. 5, pp. 539-547, Aug. 2011.

[9] C. T. Bolton, M. T. Hernández-Sánchez, M.-Á. Fuertes, S. González-Lemos, L. Abrevaya, A. Mendez-Vicente, J.-A. Flores, I. Probert, L. Giosan, J. Johnson, and H. M. Stoll, "Decrease in coccolithophore calcification and $\mathrm{CO} 2$ since the middle Miocene," Nature Communications, vol. 7, p. 10284, 2016.

[10] B. H. J. Yap, S. A. Crawford, R. R. Dagastine, P. J. Scales, and G. J. O. Martin, "Nitrogen deprivation of microalgae: effect on cell size, cell wall thickness, cell strength, and resistance to mechanical 
disruption," Journal of Industrial Microbiology \& Biotechnology, vol. 43, no. 12, pp. 1671-1680, 2016.

[11] R. Praveenkumar, K. Lee, J. Lee, and Y.-K. Oh, "Breaking dormancy: an energy-efficient means of recovering astaxanthin from microalgae," Green Chemistry, vol. 17, no. 2, pp. 12261234, 2015.

[12] S. Y. Lee, J. M. Cho, Y. K. Chang, and Y.-K. Oh, "Cell disruption and lipid extraction for microalgal biorefineries: A review," Bioresource Technology, vol. 244, pp. 1317-1328, 2017.

[13] M. Jahanshahi, Y. Sun, E. Santos, A. Pacek, T. T. Franco, A. Nienow, and A. Lyddiatt, "Operational intensification by direct product sequestration from cell disruptates: Application of a pellicular adsorbent in a mechanically integrated disruptionfluidised bed adsorption process," Biotechnology and Bioengineering, vol. 80, no. 2, pp. 201-212, 2002.

[14] X. Wu, E. M. Joyce, and T. J. Mason, "The effects of ultrasound on cyanobacteria," Harmful Algae, vol. 10, no. 6, pp. 738-743, 2011.

[15] J. Cheng, J. Sun, Y. Huang, J. Feng, J. Zhou, and K. Cen, "Dynamic microstructures and fractal characterization of cell wall disruption for microwave irradiation-assisted lipid extraction from wet microalgae," Bioresource Technology, vol. 150, pp. 67-72, 2013.

[16] I. L. Olmstead, S. E. Kentish, P. J. Scales, and G. J. Martin, "Low solvent, low temperature method for extracting biodiesel lipids from concentrated microalgal biomass," Bioresource Technology, vol. 148, pp. 615-619, 2013.

[17] D. Chiaramonti, M. Prussi, M. Buffi, A. M. Rizzo, and L. Pari, "Review and experimental study on pyrolysis and hydrothermal liquefaction of microalgae for biofuel production," Applied Energy, vol. 185, pp. 963-972, 2017.

[18] K.-Y. Show, D.-J. Lee, J.-H. Tay, T.-M. Lee, and J.-S. Chang, "Microalgal drying and cell disruption - Recent advances," Bioresource Technology, vol. 184, pp. 258-266, 2015.

[19] E. Günerken, E. Dhondt, M. Eppink, L. Garcia-Gonzalez, K. Elst, and R. Wijffels, "Cell disruption for microalgae biorefineries," Biotechnology Advances, vol. 33, no. 2, pp. 243260, 2015.

[20] I. Lee and J.-I. Han, "Simultaneous treatment (cell disruption and lipid extraction) of wet microalgae using hydrodynamic cavitation for enhancing the lipid yield," Bioresource Technology, vol. 186, pp. 246-251, 2015.

[21] M. Shafiei, M. M. Kabir, H. Zilouei, I. S. Horváth, and K. Karimi, "Techno-economical study of biogas production improved by steam explosion pretreatment," Bioresource Technology, vol. 148, pp. 53-60, 2013.

[22] E. K. Dunn, D. A. Shoue, X. Huang, R. E. Kline, A. L. Mackay, N. C. Carpita, I. E. Taylor, and D. F. Mandoli, "Spectroscopic and Biochemical Analysis of Regions of the Cell Wall of the Unicellular Mannan Weed, Acetabularia acetabulum," Plant and Cell Physiology, vol. 48, no. 1, pp. 122-133, Dec. 2006.

[23] Dunn, J. H., \& Wolk, C. P. "Composition of the cellular envelopes of Anabaena cylindrica. Journal of bacteriology", 103(1), 153158. 1970.

[24] K.-H. Schleifer and O. Kandler, "Zur chemischen Zusammensetzung der Zellwand der Streptokokken," Archiv fr Mikrobiologie, vol. 57, no. 4, pp. 365-381, 1967.
[25] A. J. Simpson, X. Zang, R. Kramer, and P. G. Hatcher, "New insights on the structure of algaenan from Botryoccocus braunii race $\mathrm{A}$ and its hexane insoluble botryals based on multidimensional NMR spectroscopy and electrospray-mass spectrometry techniques," Phytochemistry, vol. 62, no. 5, pp. $783-$ 796, 2003

[26] Kloareg, B., \& Quatrano, R. S. "Structure of the cell walls of marine algae and ecophysiological functions of the matrix polysaccharides". Oceanography And Marine Biology: An Annual Review, 26, 259-315. 1988.

[27] K. Bollig, M. Lamshöft, K. Schweimer, F.-J. Marner, H. Budzikiewicz, and S. Waffenschmidt, "Structural analysis of linear hydroxyproline-bound O-glycans of Chlamydomonas reinhardtii - conservation of the inner core in Chlamydomonas and land plants," Carbohydrate Research, vol. 342, no. 17, pp. 2557-2566, 2007.

[28] E. Braun and H. G. Aach, "Enzymatic degradation of the cell wall of Chlorella," Planta, vol. 126, no. 2, pp. 181-185, 1975.

[29] H. G. Gerken, B. Donohoe, and E. P. Knoshaug, "Enzymatic cell wall degradation of Chlorella vulgaris and other microalgae for biofuels production," Planta, vol. 237, no. 1, pp. 239-253, 2012.

[30] E. Loos and D. Meindl, "Composition of the cell wall of Chlorella fusca," Planta, vol. 156, no. 3, pp. 270-273, 1982.

[31] Graham, L. E., \& Wilcox, L. W. “ Introduction to the algae: occurrence, relationships, nutrition, definition, general features. Algae”, Prentice-Hall, Upper Saddle River, NJ. p, 640. 2000.

[32] M. Blumreisinger, D. Meindl, and E. Loos, "Cell wall composition of chlorococcal algae," Phytochemistry, vol. 22, no. 7, pp. 1603 1604, 1983.

[33] D. H. Northcote, K. J. Goulding, and R. W. Horne, "The chemical composition and structure of the cell wall ofChlorella pyrenoidosa," Biochemical Journal, vol. 70, no. 3, pp. 391-397, 1958.

[34] J.-Y. Park, M. S. Park, Y.-C. Lee, and J.-W. Yang, "Advances in direct transesterification of algal oils from wet biomass," Bioresource Technology, vol. 184, pp. 267-275, 2015.

[35] D.-Y. Kim, D. Vijayan, R. Praveenkumar, J.-I. Han, K. Lee, J.-Y. Park, W.-S. Chang, J.-S. Lee, and Y.-K. Oh, "Cell-wall disruption and lipid/astaxanthin extraction from microalgae: Chlorella and Haematococcus," Bioresource Technology, vol. 199, pp. 300-310, 2016.

[36] J. M. Estevez, P. V. Fernández, L. Kasulin, P. Dupree, and M. Ciancia, "Chemical and in situ characterization of macromolecular components of the cell walls from the green seaweed Codium fragile," Glycobiology, vol. 19, no. 3, pp. 212-228, Feb. 2008.

[37] H. R. Felix, R. Chollet, and J. Harr, "Use of the cell wall-less alga Dunaliella bioculata in herbicide screening tests," Annals of Applied Biology, vol. 113, no. 1, pp. 55-60, 1988.

[38] L. Brennan and P. Owende, "Biofuels from microalgae - A review of technologies for production, processing, and extractions of biofuels and co-products," Renewable and Sustainable Energy Reviews, vol. 14, no. 2, pp. 557-577, 2010.

[39] I. Michalak and K. Chojnacka, "Algal extracts: Technology and advances," Engineering in Life Sciences, vol. 14, no. 6, pp. 581591, 2014. 
[40] C. L. Teo and A. Idris, "Enhancing the various solvent extraction method via microwave irradiation for extraction of lipids from marine microalgae in biodiesel production," Bioresource Technology, vol. 171, pp. 477-481, 2014.

[41] A. Piasecka, I. Krzemińska, and J. Tys, "Physical Methods of Microalgal Biomass Pretreatment," International Agrophysics, vol. 28, no. 3, pp. 341-348, 2014.

[42] M. V. Derakhshan, B. Nasernejad, M. Dadvar, and M. Hamidi, "Pretreatment and kinetics of oil extraction from algae for biodiesel production," Asia-Pacific Journal of Chemical Engineering, vol. 9, no. 5, pp. 629-637, 2014.

[43] A. M. P. Neto, R. A. S. D. Souza, A. D. Leon-Nino, J. D. A. D. Costa, R. S. Tiburcio, T. A. Nunes, T. C. S. D. Mello, F. T. Kanemoto, F. M. P. Saldanha-Corrêa, and S. M. F. Gianesella, "Improvement in microalgae lipid extraction using a sonicationassisted method," Renewable Energy, vol. 55, pp. 525-531, 2013.

[44] G. S. Araujo, L. J. Matos, J. O. Fernandes, S. J. Cartaxo, L. R. Gonçalves, F. A. Fernandes, and W. R. Farias, "Extraction of lipids from microalgae by ultrasound application: Prospection of the optimal extraction method," Ultrasonics Sonochemistry, vol. 20, no. 1, pp. 95-98, 2013.

\section{AUTHORS PROFILE}

Mr. Umar Faruk J. Meeranayak, obtained his M.Sc. in 2015 from Karnatak University Dharwad and currently pursuing his Ph.D. in the Department of Biotechnology and Microbiology, Karnatak University, Dharwad under the guidance of Dr. Shivasharana C.T. His current area of Research is Algal Biodiversity

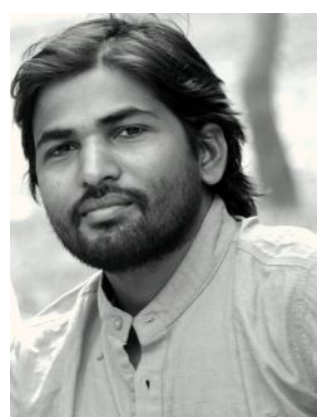
and its role in biomedical and neutraceuticals. For his outstanding efforts in understanding science and technology and stimulation of scientific attitude through participation and excellence in scientific events during the years 2005-06, 2006-07 and 2007-08, he received District young scientist award and State young scientist award. In 2012, active participation in spreading the scientific knowledge, thrust for his scientific temper was recognized and he received "Rahul Gandhi young Indian achievers National award". He has participated in more than 30 conferences, seminars, exhibitions and workshops. He has found multiple routes for spreading the scientific knowledge through radio talks, writing books, as a resource person in scientific talks and he is currently writing popular Science articles in a renowned Kannada news papers and Science journals.
Dr. Shivasharana C.T. had completed M.Sc. (2000) M.Phil. (2001) and Ph.D (2005) in Biotechnology, from Department of Biotechnology, Gulbarga University, Gulbarga. $\mathrm{He}$ is working as an Assistant Professor in the Department of Biotechnology and Microbiology, Karnatak University, Dharwad

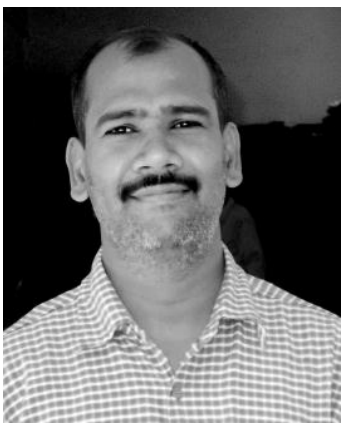
since 2008. He is working in the field of Environment and Sustainable Technology (Algal Biotechnology). He has guided 2 Ph.D students and 8 are currently working under him. He has 18 research papers and 4 book chapters published in international journals. He has attended more than 50 international/national conferences and symposia, workshops, was a resource person, invited speaker, presented papers in several such events. 